\title{
Butachlor Influence on Selected Metabolic Processes of Plant Cells and Tissues
}

\author{
Shin-Shinge Chang, ${ }^{1}$ Floyd M. Ashton, ${ }^{2}$ and David E. Bayer ${ }^{2}$ \\ 'Department of Agronomy, National Taiwan University, Taipei. Taiwan, and 'Department of \\ Botany, University of California. Davis, California 95616 USA
}

Received September 6, 1984; accepted October 31, 1984

\begin{abstract}
Time- and concentration-course studies were conducted to determine the effects of butachlor ( $\mathrm{N}$-[butoxymethyl]-2-chloro-2',6'-diethylacetanilide) on photosynthesis, protein synthesis, RNA synthesis, and lipid synthesis using isolated leaf cells of red kidney bean (Phaseolus vulgaris L.). At the 2-h incubation period, butachlor inhibited photosynthesis, protein synthesis, RNA synthesis, and lipid synthesis $99,99,96$, and $81 \%$ respectively at $100 \mu \mathrm{M}$, and $0,19,17$, and $40 \%$ respectively at $10 \mu \mathrm{M}$. At $100 \mu \mathrm{M}$ and 15-, 30-, and 60-min incubations, RNA synthesis was inhibited 20,76 and $90 \%$ respectively, and lipid synthesis 35,48 , and $62 \%$ respectively; phötosynthesis and protein synthesis were inhibited over $90 \%$ at all of these time periods. The effects of $50 \mu \mathrm{M}$ butachlor on protein and RNA synthesis in rice (Oryza sativa L.) and barnyardgrass (Echinochloa crusgalli L.) root and shoot segments were also investigated. Protein synthesis was inhibited in both species and to a greater degree in roots $(81-90 \%)$ than in shoots (55-65\%). RNA synthesis was inhibited $33 \%$ in barnyardgrass roots but not significantly in barnyardgrass shoots or either organ of rice.
\end{abstract}

Butachlor (N-[butoxymethyl]-2-chloro-2',6'-diethylacetanilide) is a soil-applied herbicide used to control annual grass and broadleaf weeds in rice (Chang 1971, Chung and Kwon 1981). This herbicide did not reduce the germination of rice or barnyardgrass seeds (Liu 1981, Chen et al. 1981), but it did inhibit the growth of rice seedling from germination stage to two-leaf stage (Liu 1981, Noriel 1981) and to six-leaf stage (Chung and Kwon 1981). Butachlor caused a greater growth reduction of rice seedlings when the herbicide was applied to the shoot zone compared with the root zone (Nangju et al. 1976). 
Chen et al. (1981) reported that amylase and protease activity of barnyardgrass seeds were reduced by $6 \mathrm{ppm}$ butachlor. The inhibition prevented the degradation of reserved protein in seeds. Noriel (1981) showed that protein synthesis from pregermination to shoot emergence in rice was inhibited by butachlor at 10 and $50 \mathrm{ppm}$, but it did not inhibit protein synthesis at the first and second leaf stages. Chung and Kwon (1981) reported that butachlor was adsorbed more to lipid than to protein material.

The studies in this report were conducted to determine the effect of butachlor on certain aspects of plant metabolism in the isolated cells. The effects of butachlor on protein synthesis and RNA synthesis of rice and barnyardgrass tissues were also determined.

\section{Materials and Methods}

\section{Isolated Cells}

Cells of the primary leaves of 7-day-old red kidney bean (Phaseolus vulgaris L.) seedlings were isolated by the method described by Ashton et al. (1977). Tissues were macerated in a medium containing $0.7 \mathrm{M}$ sorbitol, potassium dextran sulfate, and Macerase (Calbiochem). The isolated cells were washed in washing medium containing $0.65 \mathrm{M}$ sorbitol and inorganic salts and then incubated in an incubation medium containing $0.625 \mathrm{M}$ sorbitol, inorganic salts, and MES buffer. All media were adjusted to $\mathrm{pH} 5.8$. The cell preparation used for these assays contained $0.02 \mathrm{mg}$ of chlorophyll/ml. Two and one-half milliliters of the cell preparation was placed in each 25-ml Erlenmeyer flask. Each flask contained $0.1 \mathrm{ml}$ of the appropriate radioactive substrate and $0.05 \mathrm{ml}$ of the herbicide solution, making a final volume of $2.65 \mathrm{ml}$. The analytical grade butachlor was first dissolved in $53 \%$ ethanol and then diluted to give a final concentration of $1 \%$ ethanol in the incubation medium. One percent ethanol has only a slight effect on these processes in this system (DeVilliers et al. 1977). The herbicide concentrations in the incubation media were $0,0.01,0.1$, 1,10 , or $100 \mu \mathrm{M}$. The treated cells from each concentration were harvested after $15,30,60$ and $120 \mathrm{~min}$.

The assay methods for the processes studied were essentially the same as those used by Ashton et al. (1977) and Ashton and Glenn (1982). The stoppered flasks were placed in a shaking water bath at $25^{\circ} \mathrm{C}$ and illuminated from above with an intensity of 4,300 lux at the level of the flasks. Samples were removed after the designed incubation period and treated as previously described (Ashton et al. 1977) prior to liquid scintillation counting. Photosynthesis was assayed by incubating the cells with $5 \mu \mathrm{Ci}$ of $\mathrm{NaH}^{1+} \mathrm{CO}_{3}$ containing $6 \mathrm{mM}$ $\mathrm{NaH}^{12} \mathrm{CO}_{3}$. RNA synthesis was determined by measuring the incorporation of $5 \mu \mathrm{Ci}$ of $2{ }^{14} \mathrm{C}$ uracil into RNA. Protein synthesis was determined by measuring the incorporation of $1 \mu \mathrm{Ci}$ of $\mathrm{L}-\left[\mathrm{U}-{ }^{14} \mathrm{C}\right]$ leucine into protein. Lipid synthesis was determined by the incorporation of $1 \mu \mathrm{Ci}$ of $\left[1,2-{ }^{14} \mathrm{C}\right]$ sodium acetate into lipids. Radioactivity was determined by adding $10 \mathrm{ml}$ of scintillation fluid consisting of $0.4 \%$ PPO and $0.01 \%$ POPOP in toluene to samples and counting them in a liquid scintillation spectrometer. 
Chlorophyll content was determined by the method of Vernon (1960). One milliliter of cell suspension was added to $4 \mathrm{ml}$ of acetone, mixed, and centrifuged, and the optical density of the supernatant was measured. The rate of each process was calculated as disintegrations $/ \mathrm{min} / \mu \mathrm{g}$ chlorophyll. All assays were repeated two times with three replications. The results are presented as the average values of the assays.

\section{Excised Tissues}

Rice and barnyardgrass seeds were sterilized in $5 \%(\mathrm{v} / \mathrm{v})$ solution of sodium hypochlorite, washed three times with deionized water, soaked in deionized water for $24 \mathrm{~h}$, and then placed on a screen suspended $0.2 \mathrm{~cm}$ above an aerated, 0.25-strength, Hoagland's solution (Hoagland and Arnon 1950). The seeds were germinated in a dark growth chamber at $27^{\circ} \mathrm{C}$ for 4 days. A single one-halfcentimeter shoot segment immediately above the seed and a single $1.0-\mathrm{cm}$ root tip segment were excised from the seedlings and kept at $4^{\circ} \mathrm{C}$ until a sufficient amount had been obtained. The incubation medium used for this study contained $0.01 \mathrm{M} \mathrm{KH}_{2} \mathrm{PO}_{4}$ buffer ( $\mathrm{pH} 6.0$ ) containing $1 \%$ sucrose (w/v) and $40 \mu \mathrm{M}$ chloramphenicol (Moreland et al. 1969).

Eight segments of shoot or root were weighed and incubated in $2.5 \mathrm{ml}$ of incubation medium in a $25-\mathrm{ml}$ flask. The herbicide concentrations in the incubation medium were 0 or $50 \mu \mathrm{M}$. One microcurie of ${ }^{14} \mathrm{C}$-leucine or $5 \mu \mathrm{Ci}$ of $2-{ }^{14} \mathrm{C}$-uracil was added to each flask to determine protein or RNA synthesis in plant segments, respectively. The flasks were stoppered and placed in a $25^{\circ} \mathrm{C}$ shaking water bath for $5 \mathrm{~h}$. After the incubation period, the plant segments were washed three times with $5 \mathrm{ml}$ incubation medium containing nonlabeled L-leucine or uracil. Each sample was homogenized in $5 \mathrm{ml}$ of $12 \%$ TCA solution with a hand homogenizer. All procedures were carried out in ice, $4^{\circ} \mathrm{C}$. The homogenizer was washed three times with $5 \mathrm{ml}$ TCA and combined with homogenate. The homogenate was placed in ice for $15 \mathrm{~min}$ to complete precipitation. Following centrifugation at $1,000 \mathrm{~g}$ for $10 \mathrm{~min}$, the supernatant was discarded and the pellet was resuspended in $2 \mathrm{ml}$ of $50 \mathrm{mM} \mathrm{L}$-leucine or 30 $\mathrm{mM}$ uracil. The precipitate collected on a Whatman glass fiber filter was washed three times with $4 \mathrm{ml}$ of $10 \%$ cold TCA, three times with $4 \mathrm{ml}$ of $80 \%$ ethanol, twice with $4 \mathrm{ml}$ acetone, and twice with $4 \mathrm{ml}$ diethylether. The washed precipitate and filter were dried and counted in a toluene-based liquid scintillant as peviously described. Protein synthesis and RNA synthesis were calculated as DPM/mg fresh weight.

\section{Results \\ Isolated Cell}

The effects of butachlor on the four processes in red kidney bean cells are presented in Table 1 . The data are presented in two ways-DPM/ $\mu \mathrm{g}$ chlorophyll, and percent inhibition relative to the control for each incubation period. 


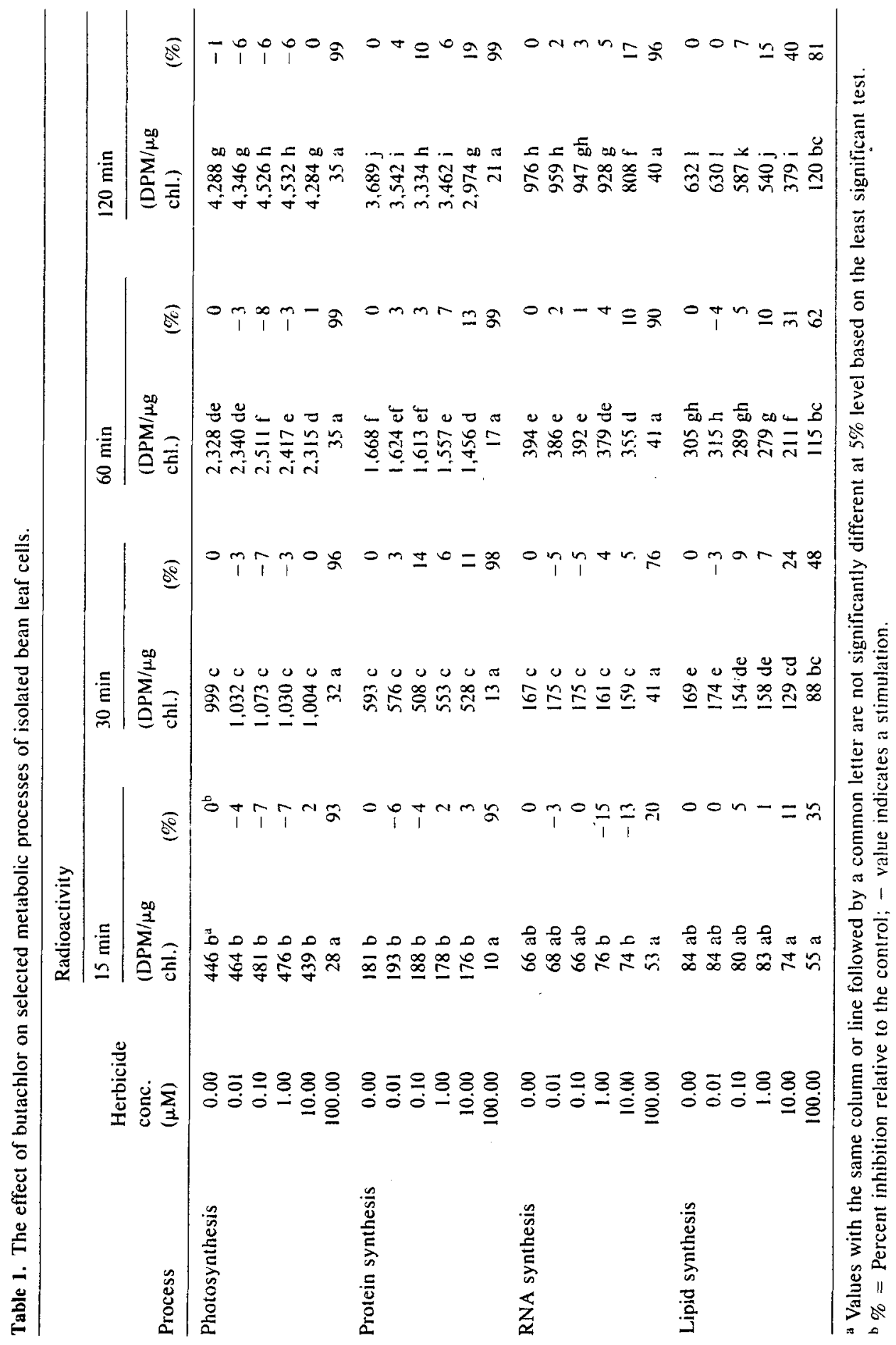


Both values are useful but may appear to be contradictory in some cases if not examined with care. For example, the inhibition of RNA synthesis at 100 $\mu \mathrm{M}$ appears to increase with time (20\% to $96 \%$ from 15 to $120 \mathrm{~min}$ ) when the rate is calculated as a percent of the control, whereas the $\mathrm{DPM} / \mu \mathrm{g}$ chlorophyll values show no increased inhibition of RNA synthesis with time. The increased inhibition reflected by the percentage values reflects the increase in control values and not an increase with inhibition of RNA synthesis per se. This anomaly is usually apparent only at intermediate values when the degree of inhibition of a given process remains relatively constant with time and the control increases normally.

The control value, DPM/ $\mu$ g chlorophyll, of each process increased relatively uniformly with time. At $10 \mu \mathrm{M}$ butachlor and lower, based on DPM $/ \mu \mathrm{g}$ chlorophyll, each process also increased uniformly with time. However, this increase was at a reduced rate relative to the controls in some cases. At $100 \mu \mathrm{M}$ butachlor, based on DPM/ $\mu \mathrm{g}$ chlorophyll, all processes except lipid synthesis were maximally inhibited at $15 \mathrm{~min}$ and did not increase with time. The increase in lipid synthesis at this concentration was relatively small with time. Significant responses were usually only apparent at 10 and $100 \mathrm{M}$ butachlor.

Photosynthesis was not inhibited by butachlor concentrations from 0.01 to $10 \mu \mathrm{M}$ within 15 to $120 \mathrm{~min}$, but was essentially blocked at $100 \mu \mathrm{M}$ in all incubation periods.

Protein synthesis was not reduced by butachlor concentrations from 0.01 to $10 \mu \mathrm{m}$ during 15 - and 30 -min incubation periods but were affected in 60 and $120 \mathrm{~min}$ at certain concentrations. Protein synthesis was essentially blocked, $95-99 \%$, at $100 \mu \mathrm{M}$ in all incubation periods. This process was also somewhat inhibited at $10 \mu \mathrm{M}, 13 \%$ and $19 \%$ in 60 and 120 min, respectively; and slightly inhibited, $7 \%$ in $60 \mathrm{~min}$ at $1 \mu \mathrm{M}$ and $4-10 \%$ in $120 \mathrm{~min}$ at 0.01 to $1 \mu \mathrm{M}$.

RNA synthesis was inhibited 5,17 , and $96 \%$ at 1,10 , and $100 \mu \mathrm{M}$, respectively, in $120 \mathrm{~min}$. The degree of inhibition was slightly less in $60 \mathrm{~min}$ at 1 and $10 \mu \mathrm{M}$. The lower concentration of butachlor and shorter exposure times showed no significant inhibition of RNA synthesis. At $100 \mu \mathrm{M}$ butachlor, RNA synthesis was not statistically different from the control at $15 \mathrm{~min}$, and it did not increase statistically with time based on DPM/ $\mu$ g chlorophyll. However, based on percent of control, the degree of inhibition of RNA synthesis increased from $20 \%$ to $96 \%$ from 15 to $120 \mathrm{~min}$. The reason for this apparent anomaly is discussed in the first paragraph of this section.

Lipid synthesis inhibition increased with increasing butachlor concentration and time. At 0.1 and $1.0 \mu \mathrm{M}$, lipid synthesis was significantly inhibited in 120 min; in shorter times, this process was not significantly inhibited at lower concentrations of butachlor. Lipid synthesis was significantly reduced 24,31 , and $40 \%$ at $10 \mu \mathrm{M}$ in 30,60 , and $120 \mathrm{~min}$, respectively. The reduction at 100 $\mu \mathrm{M}$ was about two times greater than at $10 \mu \mathrm{M}$ for the last three incubation periods. 48,62 , and $81 \%$, respectively.

\section{Excised Tissues}

The effects of butachlor on protein and RNA synthesis of rice and barnyardgrass seedling tissues are shown in Table 2. All data are presented as DPM/ 


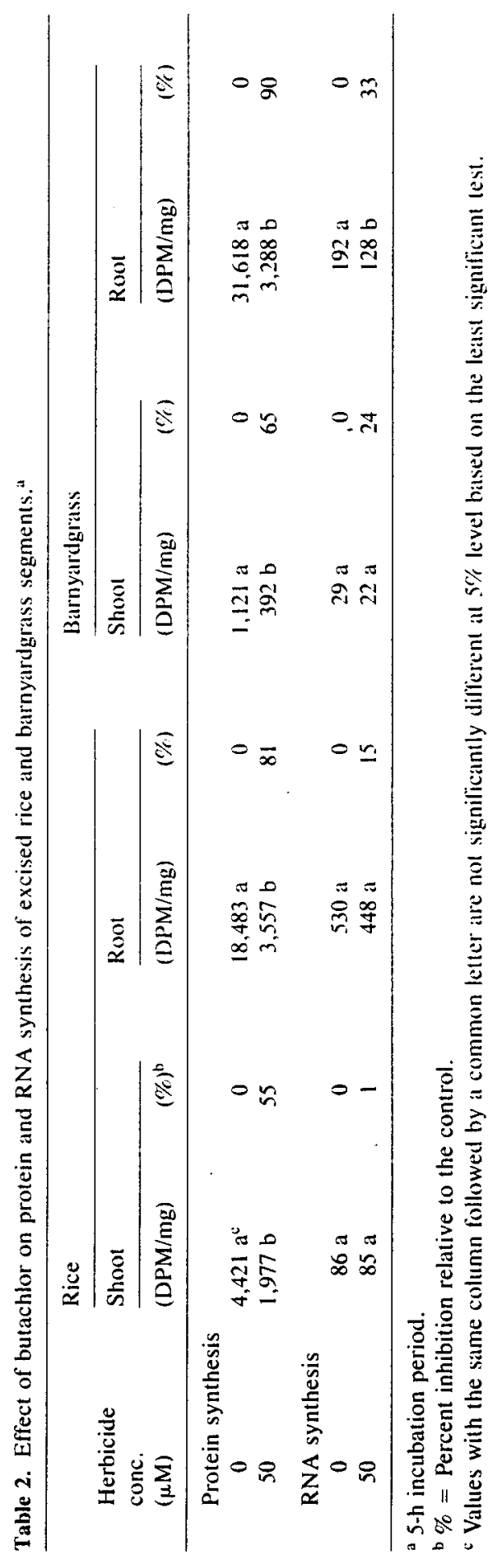


mg fresh weight. The percent inhibition is compared with the value of the control for each process.

In controls, protein synthesis in rice shoots was four times greater than in barnyardgrass shoots, whereas this process in rice root was $60 \%$ less than that of barnyardgrass roots. Protein synthesis was markedly reduced by butachlor in both species. In rice the degree of the reduction in shoot and root by $50 \mu \mathrm{M}$ butachlor were $55 \%$ and $81 \%$, respectively; in barnyardgrass the corresponding values were $65 \%$ and $90 \%$, respectively. Butachlor inhibited protein synthesis in root much more than in shoots of both species.

In controls RNA synthesis in rice shoot and root were three times greater than in barnyardgrass shoot and root. In both species this process was 6-7 times greater in the roots than in the shoots. RNA synthesis was not significantly inhibited in barnyardgrass shoots or either organ of rice. However, it was reduced moderately in barnyardgrass root, $33 \%$. RNA synthesis was less sensitive to butachlor than protein synthesis in both species.

\section{Discussion}

In the isolated bean cell system butachlor essentially blocked photosynthesis and protein synthesis within $15 \mathrm{~min}$ at $100 \mu \mathrm{M}$. RNA synthesis appeared to require $30 \mathrm{~min}$ for a similar degree of blockage at this concentration. Lipid synthesis was markedly inhibited but not blocked by this concentration at 30 to $120 \mathrm{~min}$. However, in a classical sense, the data suggest that lipid synthesis is the primary site of action of butachlor. It was inhibited at a concentration lower than any other reaction ( $1 \mu \mathrm{M}$ at $120 \mathrm{~min}$ ), and the first reaction inhibited at a given low concentration $(10 \mu \mathrm{M}$ at $30 \mathrm{~min})$. This does not take into account the possibility that the primary site of action of butachlor may be some metabolic event that has not been investigated. Lipid synthesis was inhibited more at $10 \mu \mathrm{M}$ in 120 min than protein or RNA synthesis; photosynthesis was not inhibited at $10 \mu \mathrm{M}$ at any time periods. Except for lipid synthesis at $1 \mu \mathrm{M}$ in $120 \mathrm{~min}$, none of the processes were affected at $1 \mu \mathrm{M}$ or lower concentration in any time period.

There appears to be only one previous report on the effect of butchlor on plant metabolism-namely, protein synthesis (Chung and Kwon 1981). However, there are several reports on this topic with other acetanilide-type herbicides; these will be used to supplement the discussion. Presumably, their mechanism of action is similar to that of butachlor. Using an isolated bean leaf cell system almost identical to that used in the research reported here, Ashton et al. (1977) found that in $2 \mathrm{~h}$ CDAA (N-N-diallyl-2-chloroacetamide) inhibited lipid synthesis, 56\%; protein synthesis, 29\%; RNA synthesis, $24 \%$; and photosynthesis, $18 \%$ at $1 \mathrm{mM}$. At the very high concentration of $5 \mathrm{mM}$ these inhibitions were lipid synthesis, $80 \%$; protein synthesis, 70\%; RNA synthesis, $66 \%$; and photosynthesis, $50 \%$. In general, these findings are similar to those we are reporting for butachlor, except that the degree of inhibition of each process by CDAA is less than that by butachlor, even though the CDAA concentrations are 10-50 times greater than butachlor. They considered lipid synthesis to be the most sensitive site of CDAA inhibition, as we have for 
butachlor. Mann and $\mathrm{Pu}$ (1968) reported that CDAA inhibited lipid synthesis about $88 \%$ in Sesbania exaltata hypocotyls at $120 \mu \mathrm{M}$.

Photosynthesis was not inhibited by butachlor at $10 \mu \mathrm{M}$ but was essentially blocked at $100 \mu \mathrm{M}$. Photosynthesis was the only process not inhibited to some degree at $10 \mu \mathrm{M}$. Ashton et al. (1977) found that CDAA also inhibited this process in bean leaf cells at relatively high concentrations, 1 and $5 \mathrm{mM}$. Chandler et al. (1972) reported that alachlor (2-chloro-2',6'-diethyl-N-[methyoxymethyl]acetanilide) did not inhibit the Hill reaction in isolated wheat chloroplasts at $50 \mu \mathrm{M}$.

RNA synthesis appeared to be inhibited slightly less than protein synthesis by butachlor in the bean cells. The relative difference between these two processes was much more evident in the data from the root and shoot tissue of rice and barnyardgrass. The inhibition of these two processes by CDAA was not very different in bean cells (Ashton et al. 1977). Duke et al. (1975), using propachlor (2-chloro- $N$-isopropylacetanilide) and excised cucumber roots, also found that RNA synthesis inhibition lagged behind protein synthesis and was of lower magnitude: It appears that butachlor has a direct effect on protein synthesis which occurs before the effect on RNA synthesis. Butachlor greatly affected protein synthesis in rice seeds from preemergence to shoot emergence (Noriel 1981) and prevented protease activity in barnyardgrass seed (Chen et al. 1981). Further seedling growth of both species was severely inhibited by this herbicide. Even though protein synthesis and RNA synthesis was inhibited less than lipid synthesis at $10 \mu \mathrm{M}$ butachlor, the reduction of those two processes may also contribute to the herbicidal action of butachlor over a longer period in the intact plant.

Chung and Kwon (1981) stated that "the primary mechanism of action of butachlor does not seem to be its effect on protein synthesis, but a great affinity to membranes." This statement is primarily based on data showing that butachlor at $34 \mu \mathrm{M}$ in root culture solution does not inhibit the induction and degradation of nitrite reductase in rice leaves and that butachlor is preferentially adsorbed onto liposomes of rice root lipids. The authors suggested that such binding to root membranes could reduce their permeability to water, and this could be very important for reduced growth under mild phytotoxicity. They also present confirmating data such as water uptake and diffusive resistance of leaves showing a possible altered water balance induced by butachlor. Although butachlor appears to alter water relations, and this may contribute to its phytotoxicity, the data of Chung and Kwon (1981) do not unequivocally show that an inhibition of protein synthesis is not also involved. A $34-\mu \mathrm{M}$ concentration of butachlor applied to the roots via a culture solution may not result in a sufficiently high level in the leaves to inhibit the synthesis of nitrite reductase or other proteins considering the time frame of the experiment (05 days) and the reported rapid degradation of the acetanilide-type herbicides in higher plants (Jaworski 1975, Frank et al. 1977). Furthermore, Duke et al. (1975) reported that protein biosynthesis was reduced by propachlor several hours before the observed inhibition of root growth of cucumber, therefore implicating it as the causal factor.

Protein synthesis was markedly inhibited in excised root and shoot segments of rice and barnyardgrass at a $50 \mu \mathrm{M}$ concentration. RNA synthesis was in- 
hibited less in barnyardgrass roots but not significantly inhibited in the shoots of this species or either organ of rice at this concentration. Although these processes were inhibited somewhat more in barnyardgrass (susceptible) than in rice (tolerant), the small differences observed do not appear to be of sufficient magnitude to account for their differential response to butachlor.

Acknowledgments: The authors gratefully express their appreciation to R. K. Glenn for his technical assistance, and to Monsanto Chemical Company for providing the butachlor used in this research.

\section{References}

Ashton FM, DeVilliers OT, Glenn RK, Duke WB (1977) Location of metabolic site of action of herbicides. Pestic Biochem Physiol 7:12-144

Ashton FM, Glenn RK (1982) Influence of D- and L-isomer of napromide on metabolic processes and plant growth. J Plant Growth Regul 1:277-283

Chandler JM, Croy LI, Santelmann PW (1972) Alachlor effects on plant nitrogen metabolism and Hill reaction. J Agric Food Chem 20:661-664

Chang WL (1971) Effect of the varietal type and crop season on the performance of some granular herbicides in transplanted rice. J Taiwan Agric Res 20:44-56

Chen YM, Lee LJ, Lin CY (1981) Effect of butachlor on seed germination and seedling growth of barnyardgrass. Taiwania 26:22-35

Chung BJ, Kwon YM (1981) Uptake of butachlor by rice seedling and its phytotoxic action to the physiological activities. Korea J Weed Sci 1:57-68

DeVilliers OT, Ashton FM. Glenn RK (1977) The effect of ethanol and acetone on metabolic processes in isolated plant cells. Agroplantae 9:67-70

Duke WB, Slife FW, Hanson JB. Butler HS (1975) An investigation of the mechanism of action of propachlor. Weed Sci 23:142-146

Frank R, Scrons GJ, Paik NJ. Valk M (1977) Fate of propachlor applied to onions and organic soils. Can J Plant Sci 57:473-477

Hoagland DR, Arnon DI (1950) The water-culture method for growing plants without soil. Calif Exp Stn Circ 347, Berkeley, 32 pp

Jaworski EG (1975) Chloroacetamides. In: Kearney PC. Kaufman DD (eds) Degradation of herbicides. Marcel Dekker. New York, pp 347-376

Liu A (1981) Effect of butachlor on growth and development of rice and paddy weeds. M.S. Thesis, Nation Taiwan University Taipei, Taiwan

Mann JD, Pu M (1968) Inhibition of lipid synthesis by certain herbicides. Weed Sci 16:197-198

Moreland DE, Malhotra SS, Gruenhagen RD, Shokrah EH (1969) Effect of herbicides on RNA and protein synthesis. Weed Sci 17:556-570

Nangju D, Plucknett DL, Obien SR (1976) Some factors affecting herbicide selectivity in upland rice. Weed Sci 24:63-67

Noriel LM (1981) Effect of butachlor on the protein content of C-168 and IR-36 rice cultivars at different growth stages. Ann Trop Res 3:111-116

Vernon LP (1960) Spectrophotometric determination of chlorophyll and phenophytins in plant extracts. Anal Chem 32:1144-1150 